\title{
Perbandingan Levofloxacin dengan Ciprofloxacin Peroral dalam Menurunkan Leukosituria Sebagai Profilaksis Isk pada Kateterisasi di RSUP. Dr. M. Djamil Padang
}

\author{
Marwazi Sofyan ${ }^{1}$, Alvarino $^{1}$, Erkadius $^{3}$
}

\begin{abstract}
Abstrak
Infeksi saluran kemih (ISK) adalah keadaan ketika kuman tumbuh dan berkembang biak di dalam saluran kemih dalam jumlah yang bermakna. Diagnosis ISK ditegakkan berdasarkan manifestasi klinis bakteriuria dan leukosituria. ISK pasca kateterisasi merupakan penyebab terbesar infeksi nosokomial, dengan sumber kuman bisa dari penyebaran ascending (seperti penggunaan kateter), hematogen maupun limfogen. Antibiotik profilaksis perlu diberikan untuk mencegah infeksi, mengingat tingginya kemungkinan ISK pasca kateterisasi. Flouroquinolon saat ini masih direkomendasikan untuk profilaksis ISK, namun akhir-akhir ini banyak laporan tentang resistensi terhadap golongan ini, terutama ciprofloxacin. Ciprofloxacin adalah golongan fluoroquinolon generasi kedua sedangkan Levofloxacin merupakan generasi ketiga. Di RSUP DR M Djamil, khususnya di SMF Urologi belum ada data mengenai perbandingan keefektifan levofloxacin dan ciprofloxacin ini terhadap profilaksis ISK. Oleh karena itu perlu dilakukan penelitian keefektifan levofloxacin dibandingkan dengan ciprofloxacin dalam menurunkan insiden leukosituria sebagai profilaksis ISK pada pasien yang dipasang kateter Foley. Metode: Subjek diambil dari 30 pasien yang akan dipasang kateter Foley, yang dibagi atas dua kelompok atas 15 pasien. Setelah pemasangan dilakukan urinalisis untuk menentukan kadar leukosit <10/LPB, lalu diberi Levofoloxacin $750 \mathrm{mg}$ dan Ciprofloxacin $750 \mathrm{mg}$ secara oral pada masing-masing kelompok. Tiga hari kemudian dilakukan urinalisis ulang. Hasil Penelitian: Tidak didapatkan perbedaan bermakna dalam kadar lekosit urin antara kedua kelompok baik pada hari pemasangan kateter $(p$ Fisher $=0,159)$ atau pun tiga hari kemudian ( $\mathrm{p}$ fisher $=0,097$ ). Penurunan kadar lekosit urin juga tidak bermakna antara kelompok Levofloxacin dan Ciprofloxacin (Chi-square = 1,222; P>5\%). Kesimpulan: Tidak terdapat perbedaan keefektifan antara Levofloxacin oral $750 \mathrm{mg}$ dengan Ciprofloxacin oral $750 \mathrm{mg}$ dalam menurunkan insiden leukosituria sebagai terapi profilaksis terhadap ISK pada pasien yang dipasang Foley catheter.
\end{abstract}

Kata kunci: Levofloxacin, Ciprofloxacin, Leukosituria.

\begin{abstract}
Urinary tract infection (UTI) occurred when bacteria grow and multiply in the urinary tract in significant quamtities. The diagnosis of UTI is confirmed by clinical manifestations with bacteriuria and leukocyturia. Postcatheterization UTI is the biggest cause of nosocomial infection, with the bacteria spread in ascending (such as the use of catheter), haematogenous or lymphogenous fashions. Prophylactic antibiotic is needed to prevent infection because the probability of post-catheterization UTI is high. Fluoroquinolone is currently recommended for UTI prophylaxis, however, reports about resistance to it is accumulating, especially ciprofloxacin. Ciprofloxacin is the second generation fluoroquinolone, and the later addition is Levofloxacin as the third generation fluoroquinolone. At RSUP Dr. M. Djamil, notably at the Urology section, no data is available regarding the comparison of the effectiveness between the two generations. It is therefore a research on this efficacy between those antibiotics in lowering the incidence of leukocyturia as the measure to prevent UTI in patients with Foley catheter. Method: Subjects are 30 patients with Foley catheter, divided into two groups of 15 patients each. After insertion of catheter, urinalysis was performed to determine that the lecocyte count was less than 10 per high power field of the microscope, and each group then received either Ciprofloxacin or Levofloxacin, $750 \mathrm{mg}$ orally. Urinalysis was repeated three days after the catheter wa inserted. Results: No significant differnce was found in urinary leucocyte count between the two groups, either on the day cathete was inserted ( $p$ Fisher $=0.159$ ) or three days after ( $p$ Fisher 0.097). There was no significant difference on the reduction of lucocyte count among the two groups (chi-square $=1.222 ; P>5 \%)$. Conclusion: There was no difference in effectiveness between oraly administered $750 \mathrm{mg}$ Levofloxacin and $750 \mathrm{mg}$ Ciprofloxacin in lowering the incidence of leukocyturia as prophilactic measures against UTI on patients using Foley catheter.
\end{abstract}

Keywords: Levofloxacin, Ciprofloxacin, Leukosituria.

Affiliasi penulis :1. Bagian Bedah Fak Kedokteran Unand, 2. Bagian Histologi Fak kedokteran Unand,

Korespondensi : Marwazi Sofyan email: marwazi_sofyan@yahoo.co.id Telp: 0751-31746

Pendahuluan
Infeksi saluran kemih (ISK) adalah keadaan dimana kuman tumbuh dan berkembang biak dalam saluran kemih dalam jumlah yang bermakna. Diagnosa ISK ditegakkan berdasarkan manifestasi klinis dengan bakteriuria dan leukosituria (bermakna: $\geq$ 10 / LPB atau pyuria). ISK dapat berlangsung dengan 
gejala (simptomatis) atau tanpa gejala (asimptomatis). ISK pasca kateterisasi merupakan penyebab terbesar infeksi nosokomial. Infeksi saluran kemih bisa terjadi pada saluran kemih atas (seperti pyelonephritis) maupun bawah (seperti cystitis atau urehtritis). Penyebab ISK terbanyak adalah bakteri gram negatif E.coli, penyebab lain seperti Proteus dan Klebsiella. Sumber kuman pada ISK bisa dari penyebaran ascending (seperti penggunaan kateter), hematogen maupun limfogen. 1,2,6,13,18

Infeksi saluran kemih pasca kateterisas merupakan porsi terbesar dari infeksi nosokomial. Pada penderita hipertropi prostat dengan retensio urine, pemasangan kateter merupakan suatu pertolongan, selain menghilangkan rasa nyeri juga mencegah akibat-akibat yang dapat ditimbulkan karena adanya bendungan air kemih. 2,5,10,12,15,18

Tata cara pemasangan kateter yang atraumatik dengan tindakan aseptik merupakan syarat mutlak untuk tindakan ini agar infeksi yang mungkin terjadi dapat dicegah. ${ }^{2,7,8,20}$

Walaupun sedemikian sempurnanya cara pemasangan kateter, infeksi masih saja terjadi sebesar $2 \%$ pada kateterisasi tunggal, $10 \%$ pada kateterisasi berulang dan $95-100 \%$ pada kateterisasi menetap. ${ }^{20}$

Infeksi saluran kemih pasca kateterisasi ini terjadi karena kuman dapat masuk melalui lumen kateter, rongga yang terjadi antara dinding kateter dengan mukosa uretra serta akibat bentuk muara uretra yang sulit dicapai antiseptik, sehingga kuman yang berada disini akan terdorong ke dalam kandung kemih yang pada dasarnya adalah steril. ${ }^{3,5,6,8,9}$

Infeksi kandung kemih dapat menimbulkan akibat lanjutan, bahkan sampai pyonefrosis yang akan berakhir dengan kegagalan ginjal. ${ }^{5,6,8,9}$

Hal lain yang memperburuk keadaan adalah adanya infeksi yang asimtomatis sehingga memperlambat pengobatan yang seharusnya didapat. Tingginya infeksi setelah pemasangan kateter juga sebagai akibat sulitnya pengontrolan dan perawatan serta penggantian kateter pada penderita yang memerlukan pemasangan kateter yang lama.,9

Perawatan kateter secara tertutup dapat mengurangi infeksi sampai lebih dari $50 \%$, hal ini banyak membantu menurunkan angka infeksi saluran kemih setelah pemasangan kateter. Walaupun tak dapat menghilangkannya, karena infeksi masih dapat terjadi melalui dinding kateter, sambungan antara kateter dan tabung pengumpul, serta antara tabung pengumpul dengan kantung pengumpul.,6,8,9

Pemakaian kateter menetap terbanyak dilakukan terhadap penderita hipertropi prostat,dimana Sarim melaporkan bahwa didapatkan angka infeksi saluran kemih sebelum operasi sebanyak $44 \%$ pada penderita yang dilakukan pemasangan kateter, sedang yang tidak dilakukan pemasangan kateter infeksi hanya terjadi pada $12 \%$ kasus. Lubis HR menemukan sebanyak 54\% di Medan sedang Adenan mendapatkan angka yang lebih tinggi yakni sebesar $69,2 \%$. Paper pada tahun 1978 melakukan penelitian perkembangbiakan kuman setelah pemasangan kateter, dimana didapatkan perkembangbiakan bakteri sudah terjadi dalam 24 jam, baik dengan perawatan kateter terbuka ataupun tertutup, selanjutnya didapatkan bahwa setiap harinya terjadi penambahan infeksi sebesar $5-10 \%$ bila dilakukan perawatan kateter secara tertutup, sedangkan dengan perawatan terbuka, angka infeksi sebesar 95\% dalam hari keempat. Martin C.M. mendapatkan angka infeksi sebesar $100 \%$ dalam empat hari dengan perawatan terbuka, demikian pula yang didapat oleh Levin $\mathrm{J}$, sedangkan Francies dan Landers mendapatkan angka infeksi sebesar $92 \%$ dalam waktu tiga hari. ${ }^{2,4-6,8-10,20}$

Pada pemeriksaan urine segar digunakan kriteria penemuan kuman perlapangan pandang, bila kuman ditemukan maka hasilnya dikatakan bermakna. Dengan metode ini dapat ditemukan satu atau lebih kuman, sensitifitasnya $80-100 \%$ (rata-rata 93\%) dan spesifisitasnya $60-93 \%$ (rata-rata $79 \%$ ). Bila dibandingan dengan kriteria biakan urine positif $10^{4}$ colony forming unit (CFU )/ml, sensitivitas yang tinggi juga diperoleh dengan urine mikroskopis positif. Dari penemuan adanya satu kuman perlapangan pandang diperoleh sensitifitas $72-97 \%$ dan spesifisitas $82-89 \%$, sedangkan dengan ditemukan 5 kuman perlapangan pandang diperoleh spesifisitas sebesar 99\%. Pemeriksaan ini menggunakan bilik hitung untuk darah guna menentukan jumlah leukosit dan bakteri. Bilik hitung mempunyai beberapa keuntungan antara lain memudahkan penghitungan jumlah dengan mengunakan gelas objek dan bilik hitung akan menjamin jumlah urine tetap dan merata yang akan mempermudah difusi sinar sehingga gambaran bakteri tampak lebih jelas. ${ }^{4}$

Dari penelitian Aumas P dkk, di RSUP DR M Djamil Padang didapatkan hasil dari pemeriksaan sendimen urine memiliki nilai sensitifitas yang cukup tinggi (85\%) dan spesifisitas $26 \%$, berarti pemeriksaan sendimen urine dapat menemukan $85 \%$ kasus ISK pada anak, tetapi hanya menyingkirkan $26 \%$ kasus anank yang tidak menderita ISK. ${ }^{16}$

Antibiotik profilaksis ialah antimikroba yang digunakan untuk mencegah infeksi sebelum infeksi bergejala. Antibiotik profilaksis diberikan $1 / 2$ jam sebelum tindakan dan boleh dilanjutkan maksimal 72 jam paska tindakan. Dalam Guidelines Urologi Indonesia dijelaskan bahwa waktu pemberian antibiotik profilaksis adalah antara $<1$ jam sebelum tindakan sampai maksimal 24 jam pasca tindakan dan menurut Guidelines Urologi Eropa menjelaskan bahwa waktu pemberian antibiotik untuk profilaksis adalah $<2$ jam sebelum tindakan dan tidak boleh lebih dari 3 jam setelah tindakan. Mengingat tingginya kemungkinan ISK pasca kateterisasi maka perlu diberi antibiotik profilaksis. Antibiotik golongan flouroquinolon saat ini masih direkomendasikan sebagai antibiotik profilaksis infeksi saluran kemih karena fluoroquinolone mempunyai daya antibakteri yang kuat terhadap $E$. coli, Klebsiella, Enterobacter, Proteus, H. influenzae, Providencia, Serratia, Salmonella, N. meningitidis, N. gonorrhoeae, B. catarrhalis dan Yersinia enterocolitica. Dalam Guidelines Urologi Eropa antibiotik golongan fluoroquinolon direkomendasikan sebagai antibiotik profilaksis. Namun akhir-akhir ini banyak laporan tentang resistensi golongan flouroquionolon sebagai profilaksis atau terapi ISK terutama ciprofloxacin yang berkisar antara 20\%$30 \%$. ${ }^{12,13,18-20}$

Ciprofloxacin adalah antibiotik yang termasuk dalam golongan fluoroquinolon generasi kedua sedangkan Levofloxacin merupakan generasi ketiga yang merupakan golongan kuinolon baru dengan penambahan atom fluor pada cincin kuinolon, oleh karena itu dinamakan juga Fluorokuinolon. Perubahan struktur ini secara dramatis meningkatkan daya bakterinya, memperlebar spektrum antibakteri, 
memperbaiki penyerapannya di saluran cerna, serta memperpanjang masa kerja obat. ${ }^{11,14,17}$

\section{Metode Penelitian}

Jenis penelitian ini merupakan eksprimental dengan membandingkan antara dua kelompok sampel yang dipasang foley catheter dimana masing-masing kelompok diberikan Levofloxacin 750 mg peroral dan Ciprofloxacin 750 mg peroral,kemudian dibandingkan hasil urinalisanya dengan penilaian leukosit dalam urin sebelum pemberian antibiotik tersebut diatas dan 3 hari setelah pemasangan foley chateter.

Data dikumpulkan dan diolah secara manual dan disajikan dalam bentuk tabel distribusi frekuensi setelah terdapat hasil dari urinalisa. Analisa data dilakukan secara non-parametrik.

Hasil

Penelitian telah dilakukan di RSUP. Dr. M. Djamil Padang pada 30 pasien yang ada indikasi kateterisasi urin dan dibagi menjadi 2 kelompok (tiap kelompok 15 orang). Pada kelompok A diberikan Levofloxacin oral $750 \mathrm{mg}$ dan kelompok B diberikan Ciprofloxacin oral $750 \mathrm{mg}$.

Tabel 1. Uji Urinalisa I

\begin{tabular}{lllll}
\hline Urinalisa & & & & $\mathbf{p}$ \\
$\mathbf{I}$ & A & B & Total & Fisher \\
\hline$<5$ & 3 & 6 & 9 & \\
$5 />$ & 12 & 9 & 21 & 0.159 \\
\hline Total & 15 & 15 & 30 & \\
\hline
\end{tabular}

Berdasarkan hasil analisa pada tabel diatas, didapatkan hasil leukosit pada urin pasien $<5$ LPB sebanyak 3 orang pada kelompok yang akan diberikan obat Levofloxacin oral $750 \mathrm{mg}$, lebih sedikit dibandingkan dengan kelompok yang akan diberikan obat Ciprofloxacin oral 750 mg. Kemudian, didapatkan hasil $p$ value $=0,159$ berarti $p$ value $>0,05$ berarti tidak terdapat perbedaan bermakna antara hasil leukosit pada urin yang akan diberikan Levofloxacin $750 \mathrm{mg}$ peroral dengan yang akan diberikan Ciprofloxacin $750 \mathrm{mg}$ peroral.

Tabel 2. Uji Urinalisa II

\begin{tabular}{lllcl}
\hline Urinalisa & & & & P \\
II & A & B & Total & Fisher \\
\hline$<5$ & 7 & 3 & 10 & \\
$5 />$ & 8 & 12 & 20 & 0.097 \\
\hline Total & 15 & 15 & 30 & \\
\hline
\end{tabular}

Berdasarkan hasil analisa pada tabel diatas, didapatkan hasil leukosit pada urin pasien $<5$ LPB sebanyak 7 orang pada kelompok yang telah diberikan obat Levofloxacin oral $750 \mathrm{mg}$, lebih banyak dibandingkan dengan kelompok yang telah diberikan obat Ciprofloxacin oral 750 mg. Kemudian, didapatkan hasil $p$ value $=0,097$ berarti $p$ value $>0,05$ berart tidak terdapat perbedaan bermakna antara efektifitas Levofloxacin $750 \mathrm{mg}$ peroral dengan Ciprofloxacin 750 mg peroral.
Tabel 3. Penurunan Leukosit pada Levofloxacin oral $750 \mathrm{mg}$ dan Ciprofloxacin oral $750 \mathrm{mg}$

\begin{tabular}{|l|l|l|l|l|}
\hline Penurunan & A & B & Total & $\begin{array}{l}\text { Chi } \\
\text { square }\end{array}$ \\
\hline$<5$ & 5 & 8 & 13 & \multirow{2}{*}{1,222} \\
\cline { 1 - 4 } $5 />$ & 10 & 7 & 17 & \\
\cline { 1 - 4 } Total & 15 & 15 & 30 & \\
\hline
\end{tabular}

Berdasarkan hasil analisa pada tabel diatas, didapatkan penurunan hasil leukosit pada urin pasien >/5 LPB sebanyak 10 orang pada kelompok yang telah diberikan obat Levofloxacin oral $750 \mathrm{mg}$, lebih banyak dibandingkan dengan kelompok yang telah diberikan obat Ciprofloxacin oral 750 mg. Kemudian, didapatkan hasil $p$ value $=1,222$ berarti $p$ value $>0,05$ berarti tidak terdapat perbedaan bermakna antara efektifitas Levofloxacin $750 \mathrm{mg}$ peroral dengan Ciprofloxacin 750 mg peroral.

Tabel 4. kadar leukosit urinalisa I,urinalisa II dan penurunannya

\begin{tabular}{|l|ll|ll|ll|}
\hline & Mean & & Mean & & \\
& A & SD & B & SD & P & S/NS \\
\hline Urinalisis I & 6.300 & 2.455 & 6.033 & 2.475 & 0.769 & NS \\
Urinalisis II & 1.167 & 0.724 & 1.700 & 0.775 & 0.061 & NS \\
\hline Penurunan & 5.133 & 2.167 & 4.333 & 1.877 & 0.289 & NS \\
\hline
\end{tabular}

Berdasarkan tabel di atas, pada uji urinalisa I rata-rata kadar leukosit pasien yang berada pada kelompok yang akan diberikan obat Levofloxacin oral $750 \mathrm{mg}$ hampir sama dibandingkan rata-rata kadar leukosit pasien pada kelompok yang akan diberikan obat Ciprofloxacin oral $750 \mathrm{mg}$ yaitu $6.300 \pm 2.455$ : $6.033 \pm 2.475 / \mathrm{LPB}$ dengan hasil $\mathrm{p}$ value $=0,769$. Sedangkan pada uji urinalisa II, rata-rata kadar leukosit pasien yang berada pada kelompok yang telah diberikan obat Levofloxacin oral $750 \mathrm{mg}$ sedikit lebih kecil dibandingkan rata-rata kadar leukosit pasien yang berada pada kelompok yang telah diberikan obat Ciprofloxacin oral $750 \mathrm{mg}$ yaitu $1.167 \pm 0.724: 1.700 \pm 0.775 /$ LPB dengan hasil $p$ value $=0,061$. Selanjutnya, rata-rata penurunan kadar leukosit pasien pada kelompok yang telah diberikan obat Levofloxacin oral $750 \mathrm{mg}$ lebih besar dibandingkan rata-rata kadar leukosit pasien pada kelompok yang telah diberikan obat Ciprofloxacin oral $750 \mathrm{mg}$ yaitu $5.133 \pm 2.167: 4.333 \pm 1.877 /$ LPB dengan hasil $p$ value $=0,289$. Berdasarkan hasil diatas didapatkan bahwa tidak ada perbedaan yang bermakna antara efektifitas Levofloxacin $750 \mathrm{mg}$ peroral dengan Ciprofloxacin $750 \mathrm{mg}$ peroral dalam penurunan kadar leukosit pada urin.

\section{Pembahasan}

Infeksi saluran kemih pasca kateterisasi merupakan porsi terbesar dari infeksi nosokomial. Dalam menegakkan diagnosa ISK harus didasarkan pada manifestasi klinis dengan bakteriuria dan leukosituria. Walaupun sedemikian sempurnanya cara pemasangan kateter, infeksi masih saja terjadi. Mengingat tingginya kemungkinan ISK pasca keteterisasi seperti tersebut diatas maka perlu 
diberikan antibiotik profilaksis pada saat pemasangan kateter. Antibiotik golongan florokuinolon saat ini masih direkomendasikan sebagai antibiotik profilaksis terhadap ISK.

Dalam penelitian ini, peneliti akan membandingkan efektifitas antara Levofloxacin oral dengan Ciprofloxacin oral dalam menurunkan insiden terjadinya leukosituria sebagai salah satu indikator dalam menegakkan diagnosa ISK sebagai tindakan profilaksis terhadap ISK pasca kateterisasi urin dalam hal ini foley catheter.

Telah dilakukan penelitian terhadap 30 orang pasien yang ada indikasi kateterisasi, dimana setelah dilakukan pemasangan foley chateter langsung lakukan urinalisa pertama yang kemudian dibagi menjadi 2 kelompok yang masing-masing kelompok diberikan Levofloxacin oral $750 \mathrm{mg}$ (kelompok A) dan Ciprofloxacin oral $750 \mathrm{mg}$ (kelompok B). Gambaran leukosit dalam urin pada urinalisa pertama tidak boleh $>10 /$ LPB, karena leukosit dalam urin akan bermakna bila $>10 /$ LPB (leukosituria/pyuria).

Dari Urinalisa pertama tersebut didapatkan gambaran leukosit dalam urin pada 15 sampel kelompok $A$ yang akan diberikan Levofloxacin oral 750 mg sebanyak 3 orang dengan leukosit $<5 / L P B$, dan 12 orang dengan leukosit $>5 /$ LPB dan dari 15 sampel pada kelompok B yang akan diberikan Ciprofloxacin oral $750 \mathrm{mg}$ didapatkan 5 orang dengan leukosit $<5 /$ LPB dan 10 orang dengan leukosit $>5 / L P B$. Berdasarkan analisa diatas didapatkan bahwa semua sampel tidak menunjukkan gambaran leukosituria pada urinalisa sebelum pemberian Levofloxacin oral $750 \mathrm{mg}$ atau Ciprofloxacin oral $750 \mathrm{mg}$ dan setelah dilakukan uji statistik tidak didapatkan perbedaan yang bermakna kadar leukosit dalam urin antara pasien pada kedua kelompok tersebut diatas.

Pada hari ke 3 setelah pemasangan Foley catheter, masing-masing kelompok ( $A$ dan $B)$ dilakukan urinalisa kedua. Dari urinalisa kedua didapatkan gambaran leukosit dalam urin pada 15 sampel kelompok $A$ sebanyak 7 orang dengan leukosit $<5 /$ LPB dan 8 orang dengan leukosit $>5 /$ LPB sedangkan gambaran leukosit dalam urin pada 15 sampel kelompok B didapatkan 3 orang dengan leukosit $<5 /$ LPB dan 12 orang dengan leukosit $>5 /$ LPB . Setelah dilakukan uji statistik didapatkan hasil bahwa tidak ada perbedaan bermakna kadar leukosit dalam urin antara pasien pada kolompok $\mathrm{A}$ dibandingkan dengan pasien pada kelompok $\mathrm{B}$.

Berdasarkan dari data hasil urinalisa pertama dan kedua diatas menunjukkan bahwa Levofloxacin dan Ciprofloxacin yang diberikan secara oral dengan dosis $750 \mathrm{mg}$ adalah sama-sama efektif dalam menurunkan kadar leukosit dalam urin, dimana secara teoritis sesuai dengan yang direkomendasikan dalam Guidelines Urologi dan yang ditulis dalam beberapa literatur bahwa antibiotik golongan fluorokuinolon merupakan antibiotik terpilih sebagai profilaksis terhadap ISK.

Kemudian dilakukan uji statistik dengan membandingkan efektifitas masing-masing antara Levofloxacin dan Ciprofloxacin yang diberikan secara oral dengan dosis $750 \mathrm{mg}$ dalam penurunan kadar leukosit dalam urin pada masing-masing kelompok sampel (Kelompok A diberikan Levofloxacin dan kelompok B diberikan Ciprofloxacin) didapatkan hasil bahwa tidak ada perbedaan yang bermakna tingkat efektifitas antara Pemberian Levofloxacin oral dengan Ciprofloxacin oral dalam menurunkan insiden leukosituria sebagai profilaksis ISK pada pasien yang dipasang Foley catheter.

$\mathrm{Hal}$ ini memang tidak sesuai dengan teori dari beberapa literatur yang mengatakan bahwa Levofloxacin merupakan antibiotik golongan fuorokuinolon generasi ketiga, dimana daya antibakterinya lebih kuat dan spektrumnya lebih luas bila dibandingkan dengan Ciprofloxacin yang merupakan golongan fluorokuinolon generasi kedua. Tetapi kedua antibiotik yang sama-sama merupakan golongan fluorokuinolon ini merupakan antibiotik yang mempunyai daya antibakteri yang kuat terhadap bakteri yang menyebabkan ISK, sehingga sampai saat ini masih direkomendasikan sebagai antibiotik profilaksis ISK.

\section{Kesimpulan}

1. Pemberian Levofloxacin oral $750 \mathrm{mg}$ dan Ciprofloxacin oral $750 \mathrm{mg}$ efektif dalam menurunkan insiden leukosituria pada pasien yang dipasang Foley catheter.

2. Tidak terdapat perbedaan efektifitas antara pemberian Levofloxacin oral $750 \mathrm{mg}$ dengan Ciprofloxacin oral $750 \mathrm{mg}$ dalam menurunkan insiden leukosituria sebagai terapi profilaksis terhadap ISK pada pasien yang dipasang Foley catheter.

\section{Daftar Pustaka}

1. Burkit H.J. Problem Diagnosis and Management. In: Essensial Surgery. London: Churchill Livingstone;1992.p. 405-482.

2. Cravens D.D. Urinary Catheter Management. American Family Physician. 2000. http/www.findarticles.com/cf_O/m3225/2_61/594 86856/print.jhtml.

3. Purnomo B.B. Dasar-Dasar Urologi. Jakarta: CV Infomedika; 2000: 200-214

4. Eko, Titin Nugraheni. Pemeriksaan Mikroskopis Urine untuk Diagnosis Infeksi Saluran Kemih pada Neonatus. Semarang : Universitas Diponegoro. 2003.

5. Hargreave T.B. Bladder and Prostate. In: Farquhanson's Text Book of Operative surgery. $8^{\text {th }}$ ed.London : Churchill Livingstone. $1995: 621$ 653.

6. Blandy JP. Lectures Notes on Urology. $3^{\text {th }}$ ed. Bleckwell-Scientific Publication. 1983. p. 159-221

7. Brown R.B. Clinical Urology Illustrated. ADIS Health Schience Press. 1982: 54-59.

8. Bahnson RR . Physiology of The Kidney, Ureter, and Bladder in Basic Science Review for Surgeous. edited by Simmons and Steed. D L WB Sondrs Company. 1990:270-287.

9. Ganong WF. Fisiologi Kedokteran : Berkemih (Review of Medical Physiology). Edisi 10. Diterjemahkan oleh : Adji Dharma. EGC. 1983 : 626-628.

10. Rochani. Retensio Urin dalam Kedaruratan Non Medik dan Bedah. Jakarta: Balai Penerbit FKUI. 2000: 95-98.

11. Reksoprawiro S. Ilmu Penggunaan Antibiotik Profilaksis pada Pembedahan. Surabaya Departemen/SMF IImu Bedah FK Unair/RS Dr. Soetomo.

12. Kasatpibal N, Norgaard M, Sorensen H. Risk of Surgical Site Infection and Eficiency of Antibiotic Prophylaxix : A Cohort Study of Appendectomy 
Patients in Thailand. BMC infeksious disease. 2006:6-111.

13. Dzen S.M. Kuman Penyebab Infeksi Saluran Kemih dan Kepekaannya terhadap Antibiotik. Lab. Mikrobiologi FK Unibraw. Malang: Medika. 1996 ; 12(10):944-949.

14. Nicholas R. Infeksi dan Pemilihan Antibiotik. Dalam: Buku Ajar Bedah. Editor: Sabiston D.C. Terjemahan: Adrianto $\mathrm{P}$ dan Timan. Jakarta :EGC; 1995.p. 206-207.

15. Raharjo D. Perbesaran Prostat Jinak Manifestasi Klinik Dan Manajemen. Jakarta: Ropanasuri.1997, 15(1): 37-44.

16. Aumas $\mathrm{P}$, dkk. Uji diagnostik Tiga metode Pemeriksaan Urinalisi Untuk Identifikasi Cepat Infeksi Saluran kemih pada Anak. Padang : FK UNAND;
17. Farmakologi Dan Terapi Departemen Farmakologi dan terapeutik Fakultas Kedokteran Universitas Indonesia. Jakarta. Edisi 5. 2007. Hal: $210-246$.

18. Naber KG, Bergman B, bishop MC, Johansen TEB,

19. Botto $H$, Lobel B (E.d).European Association of Urology : Guidelines on Urinary and Male Genital Tract Infection.2011: 78 - 88.

20. Iwan A,dkk. Guidelines Penatalaksanaan infeksi saluran Kemih (ISK) dan Genitalia pria 2007. Hal.: $35-37$.

21. Furqan. Evaluasi Biakan Urine pada Penderita $\mathrm{BPH}$ setelah Pemasangan Kateter menetap, Pertama kali dan Berulang. Bagian Ilmu Bedah FK USU. Medan.2003. 